\title{
ZNAČAJ FEMINISTIČKE EKONOMIJE I ŽENSKOG PODUZETNIŠTVA ZA REGIONALNI RAZVOJ
}

\author{
Lejla Softić, dipl. oec. \\ SoftConsulting s.p. Tuzla \\ Trg slobode 16, 75000 Tuzla, Bosna i Hercegovina (BiH) \\ Telefon: + 38735210 203, e-mail: lejla.softic@savjetnik.ba
}

\section{SAŽETAK}

Regionalni razvoj ne može se promatrati bez analize problematike tradicionalne ekonomije koja zanemaruje ulogu žena pri kreiranju bruto domaćeg proizvoda (BDP). Tradicionalna ekonomija ne mjeri adekvatno neplaćeni rad, obično žena pri obavljanju kućanskih poslova, brige o djeci i starijima, stoga feministička ekonomija zagovara da se istraži i vrednuje doprinos neplaćenog rada žena pri kreiranju BDP-a. Cilj istraživanja je prezentirati nevidiljivi dio doprinosa ženskih poslova pri kreiranju BDP-a, ukazati na značaj ženskog poduzetništva i potaknuti regionalni razvoj kroz edukaciju žena o poduzetništvu. U istraživanju se koristila PEST analiza trenutnog stanja u BiH, zasnovana na sekundarnim podacima iz zvaničnih statističkih $i$ drugih relevantnih publikacija koje su nastale primarnim istraživanjem ove problematike u BiH. Izvršeno je i primarno istraživanje ciljanog uzorka ispitanika iz regije, a anketiranjem su potvrđeni prezentirani rezultati u PEST analizi. Naglasak u radu je na razvoju ženskog poduzetništva, ali i generalno na socio-ekonomskoj ulozi žena u BH ekonomiji, kao i na značaju podizanja nivoa svijesti o ovoj temi u regiji. U „Izvještaju o stanju ravnopravnosti spolova u BiH" (Agencija za ravnopravnost spolova, 2018. godina), navodi se da je jednak broj dječaka i djevojčica, žena i muškaraca uključen u proces obrazovanja u BiH, ali su i dalje ograničene mogućnosti napredovanja za djevojčice/žene i pristup pozicijama za koje su potrebne visoke kvalifikacije, prije svega zbog postojanja stereotipa koji se odnose na muška/ženska zanimanja i pitanja usklađivanja profesionalnog i porodičnog života. Položaj većine žena u BH društvu je nezavidan, a njihova ekonomska i svaka druga sigurnost prilično upitna. Unatoč lošim uvjetima, žene u BiH uspjele su da opstanu, pokreću vlastite poslove i da se istovremeno uspješno brinu za svoje obitelji, ali $i$ postanu pokretači promjena u BiH i regionalnog društvenog razvoja.

Ključne riječi: feministička ekonomija; žensko poduzetništvo; razvoj 


\section{UVOD}

Pitanje ekonomske uloge žena i njihove financijske sigurnosti jedan je od aktualnih izazova za BH društvo. Da bi se na ovaj izazov mogli ponudili adekvatni odgovori, potrebno je izvršiti analizu trenutnog stanja u BiH. Pri analizi trenutne situacije ne smiju se zanemariti niti svi pozitivni pomaci, u postratnom periodu, koji su postignuti u BiH. Cilj ovog autorskog rada nije ponuditi konačne odgovore nego prezentirati neke od mogućih solucija koje se, u narednom periodu, mogu kvalitetnije primjenjivati, ukoliko se želi postići ekonomski i socijalni boljitak BH društva, prekogranična suradnja u oblasti promocije značaja razvoja ženskog poduzetništva i edukacije poduzetnica, kao jedan od oblika regionalnog razvoja.

\section{ZNAČAJ FEMINISTIČKE EKONOMIJE ZA RAZVOJ ŽENSKOG PODUZETNIŠTVA}

Za spoznaju značaja uloge žena, pri kreiranju bruto domaćeg proizvoda (BDP-a), neophodno je prezentirati osnovne značajke feminističke ekonomije. Feministička ekonomija relativno je nova grana ekonomije koja koristi feminističku perspektivu pri kritici tradicionane ekonomije i nastoji da istraži kako BDP ne mjeri adekvatno neplaćeni rad koji uglavnom čine žene, kao što su kućanski poslovi, briga o djeci i starijima. S obzirom da je najveći dio ženskih poslova nevidljiv, zagovornici feminističke ekonomije tvrde da neke od mjera, čiji je cilj povećanje BDP-a mogu, pogoršati i osiromašiti žene, iako im je namjera bila povećati opći prosperitet društva.

U 21. stoljeću milioni žena još uvijek rade na loše plaćenim i nekvalitetnim poslovima, potisnute su ograničeni broj manje cijenjenih zanimanja, uskraćuje im se osnovna zdravstvena zaštita, nemaju pristup čistoj vodi itd. Jedno od istraživanja na globalnoj razini naglašava da u domaćinstvima širom svijeta žene čine $83 \%$ pomoćnog osoblja, a skoro $50 \%$ njih nema pravo na minimalnu platu. (Ključić, 2018.) Društveno-ekonomska pozicija žena na globalnoj sceni i trenutna situacija na BH tržištu, koja će biti prezentirana u PEST analizi, manje-više je istovjetna. Ovo ne treba da bude motiv donosiocima odluka u BH ekonomiji i društvu da ne treba poduzimati ništa po ovom pitanju odnosno ženama u BiH da ne treba da budu (pro)aktivnije u oblasti poboljšanja vlastitog ekonomskog položaja u BH društvu. Žene u BH društvu, ukoliko žele postići vlastitu financijsku samostalnost i osigurati odgovarajuću financijsku sigurnost za svoju obitelj, trebaju više vremenskih i drugih resursa ulagati u osobnu financijsku pismenost i poduzetničko obrazovanje. lako je isti broj dječaka i djevojčica, odnosno žena i muškaraca uključen u proces obrazovanja u BiH, ženama su ograničene mogućnosti napredovanja i pristup pozicijama za koje su potrebne visoke kvalifikacije, zbog stereotipa u društvu, kako u oblasti izbora zanimanja, tako i po pitanju usklađivanja profesionalnog i porodičnog života. (Izvještaj o stanju ravnopravnosti spolova u $\mathrm{BiH}, 2018$.

Znajući da feministička ekonomija stavlja fokus na oblasti koje se ne uključuju u agregatne, makroekonomske pokazatelje kao što je neplaćeni kućni rad, briga o djeci, briga o starijim osobama, odnosno da za makroekonomske ciljeve predviđa da budu vođeni etikom brige, to se kao prirodna potreba žena, pri osiguravanju vlastite financijske samostalnosti i financijske sigurnosti svoje obitelji, sve više pojavljuju alternativni oblici ekonomske moći koja se zasniva na načelima suradnje, solidarnosti, zajedničke imovine, ekološke održivosti 
i otvorenosti. Najbolji primjeri takvih načina ekonomskog organiziranja žena su: žensko i socijalno poduzetništvo.

\section{3. (PRED)RATNE OKOLNOSTI U BIH}

Ratne okolnosti u značajnoj su mjeri utjecale na promjene u $\mathrm{BH}$ ekonomiji i društvu. Ovo se posebno odnosilo na ekonomsku i političku ulogu žena, kao uvriježeno slabiji spol, u tradicionalnim društvima, kakvo je i BH društvo. Žene su tijekom ratnih događanja ostajale bez muških članova obitelji, koji su u tradicionalnim uvjetima života i rada, u kakvim je bilo BH društvo prije i tijekom rata, imali ulogu hranitelja obitelji, a što je bilo naročito izraženo u ruralnim dijelovima $\mathrm{BiH}$.

O ulozi žena u predratnoj BiH najbolje govori podatak da je u Parlamentarnoj skupštini BiH nakon tzv. prvih demokratskih izbora 1990. godine bilo izabrano svega 7 žena od ukupno 240 zastupničkih mjesta, odnosno žene su procentualno činile 2,92\% parlamentarnih poslanika/ca (Aganović, Miftari, Veličković, 2015.). Početkom rata, žene su bile skoro potpuno nevidljive na političkoj sceni u $\mathrm{BiH}$, što može biti objašnjeno i sa činjenicom da $u$ ratnim okolnostima tradicionalna uloga muškarca kao zaštitnika postaje posebno vidljiva i dominantna, dok se tradicionalna uloga žene isključivo povezuje s domom i majčinstvom, koje je u ratnim okolnostima bio jedan od privatnih aspekata života i samim time manje vidljiv u političkom smislu riječi. Tradicionalna uloga žena nije politička, a žene se prije svega vide kao: supruge, majke i kćerke odnosno čuvarice ognjišta i obitelji, a ne društva (države) kao cjeline, iako je obitelj osnovna ćelija svake društvene zajednice (države).

Žene koje su uslijed ratnih okolnosti ostale bez muškaraca, kao tradicionalnih hranitelja u obitelji, ali i druge žene čiji su muževi npr. ostali bez zaposlenja uslijed ratnih okolnosti, tokom kojih su u cijelosti devastirani proizvodni kapaciteti u $\mathrm{BiH}$ i generalno $\mathrm{BH}$ ekonomija, trebale su se potpuno samostalno izboriti za vlastitu egzistenciju i ekonomsku sigurnost svoje obitelji. Koliko je bila uspješna borba žena za vlastitu egzistenciju i egzistenciju njihovih obitelji prezentirano je u PEST analizi trenutnog stanja u $\mathrm{BiH}$.

\section{PEST ANALIZA TRENUTNOG STANJA U BiH}

Za potrebe analize trenutog stanja u BiH korištena je tzv. PEST analiza. PEST analiza je akronim za: političke, ekonomske, sociološke i tehnološke aspekte koji se posmatraju kada se vrši analiza makro okruženja, za potrebe donošenja odgovarajućih odluka i planova za budućnost.

\subsection{Političko okruženje}

lako u BiH postoji Zakon o ravnopravnosti spolova iz 2003. godine, a lokalne zajednice formalno imaju pravna akta koja su usklađena s ovim Zakonom, problematika u ovoj oblasti i dalje postoji pri njihovoj implementaciji. Lokalne zajednice u $\mathrm{BiH}$ ne primjenjuju rodno osjetljivo budžetiranje, iako su ispunjeni svi potrebni formalno-pravni preduvjeti. (Miftari, 2017.) Ovo je najbolji pokazatelj koji govori o ekonomskom položaju žena u BiH odnosno o neadekvatnosti političkog i ekonomskog ambijenta u BiH. 
Istraživanjem o političkom djelovanju žena utvrđeno je da nasilje nad ženama u BH politici ima različite oblike, od mizoginistički i seksistički verbalnih napada, do relativno manjih oblika online uznemiravanja i seksualnog uznemiravanja, a 60,20\% od 83 sudionice istraživanja iskusilo je, tokom bavljenja politikom, neku formu nasilja (Miftari, 2019.). Da nasilje nad ženama u politici najčešće poprima oblik verbalnog i emocionalnog zlostavljanja smatra $96,40 \%$ ispitanica, a da je internet važan kanal za psihološko nasilje nad ženama u politici te da su političarke često izložene i mrežnom nasilju. Cilj im je obeshrabriti žene od politički aktivnog djelovanja u $\mathrm{BiH}$, pri ostvarivanju svojih ljudskih prava, utjecaja na $\mathrm{BH}$ društvo te ograničiti ili spriječiti političko sudjelovanje žena kao pojedinca i/ili žena kao grupa.

Ukoliko su žene u politici izložene ovakvoj vrsti nasilja, ne može se očekivati da će politički i društveni ambijent u BiH biti skloniji prema drugim oblicima aktivizma žena pri njihovom nastojanju da ostvare ekonomska i druga zakonom zagarantirana ljudska prava.

\subsection{Ekonomsko okruženje}

BH ekonomsko okruženje još uvijek nije dovoljno brzo napredovalo da bi se na tržištu rada stvorili kvalitetni financijski preduvjeti i dostatno financijsko blagostanje koje bi omogućilo i veću ekonomsku samostalnost žena.

U Izvještaju Svjetskog ekonomskog foruma procijenjuje se da je godišnja zarada žena u BiH oko 11.300 BAM $^{1}$, dok je godišnja zarada muškaraca oko 26.500 BAM, što je duplo veći iznos, koji vrlo jasno pokazuje da žene i muškarci nemaju jednake ekonomske mogućnosti, čak i ako su zaposleni/e (Knežević, 2016.). Stoga je, u narednom periodu, neophodno da veći naglasak bude na gender senzitivnom budžetiranju, kao jednom od načina za postizanje ekonomske ravnopravnosti spolova u $\mathrm{BiH}$, naročito tijekom pripreme budžeta $\mathrm{u}$ institucijama i javnim poduzećima u $\mathrm{BiH}$, ali i pri raspodjeli financijskih resursa u drugim granama BH privrede.

U BiH postoji značajan rodni dispariteti u segmentu zaposlenosti žena i muškaraca po pojedinim sektorima. Rodne razlike postoje i u zaradama žena i muškaraca u svim platnim razredima, izuzev u najvišem (preko 2.500 BAM) i najnižem (200 BAM) platnom razredu (Bašić, Miković, 2012.). Istraživanjem je utvrđeno sljedeće:

- $\quad 67,40 \%$ ispitanica prilikom razgovora za dobivanje posla susrelo se s praksom postavljanja pitanja o bračnom statusu i broju djece

- $\quad 51,20 \%$ ispitanica posjeduje iskustvo s pitanjima o namjerama rađanja i planiranju obitelji

- $\quad 62,30 \%$ ispitanica imalo je iskustvo i s postavljanjem drugih pitanja intimne prirode

- $\quad$ samo $18,10 \%$ ispitanica smatra da su na BH tržištu rada obje rodne grupe jednako plaćene za isti rad.

lako je istraživanje izvršeno prije jednog desetljeća, informacije iz medija koje su novijeg datuma upućuju na nepromjenjeno stanje. Jedan od problema, koje je aktualno na BH medijima, je i pitanje npr. nejednakog prava porodilja u BiH. Različiti propisi u svakom

1 Op.a. BAM - konvertibilna marka je zvanična valuta u BiH. $1 \mathrm{HRK}=0.25 \mathrm{BAM}$ odnosno $1 \mathrm{BAM}=4 \mathrm{HRK}$. 
kantonu (županiji) ${ }^{2}$ rezultiraju neujednačenim visinama porodiljnih naknada u različitim dijelovima iste države i koji se kreću za nezaposlenu porodilju u rasponu od 150 BAM kao jednokratna naknada u Zeničko - dobojskom kantonu, do 266 BAM - kao mjesečna naknada u Kantonu Sarajevo. Ništa bolja situacija nije ni sa ostvarivanjem prava porodilja koje su zaposlene u različitim dijelovima $\mathrm{BiH}$, a koje imaju pravo na iznos naknade u rasponu $30 \%$ - 60\% prosječne plaće u $\mathrm{FBiH}^{3}$, dok porodilje u $\mathrm{RS}^{4}$ imaju pravo na naknadu plaće u visini prosječne plaće koju su ostvarile u toku posljednjih 12 mjeseci. (Agić, 2019.)

Trenutno stanje u BiH je nezadovoljavajuće, ali ne treba zanemariti činjenicu da $\mathrm{BH}$ ekonomska stvarnost bilježi i pozitivne pomake kada je u pitanju ekonomija i aktivnosti žena - menadžerica. „Žene menadžerice u BiH, u 2017. godini, ostvarile su 3,2 milijarde BAM prihoda. Od ukupnog prihoda, 793 miliona BAM ostvareni su kroz izvoz proizvoda i usluga, dok je ukupna ostvarena dobit 205 miliona BAM. Ovi podaci najbolji su dokaz da su žene menadžerice značajan faktor BH ekonomskog razvoja, a njih ukupno 149 je na čelu nekih od najuspješnijih poduzeća. Od ukupno 787 poduzeća, istraživanjem je utvrđeno da 19\% poduzeća vode žene menadžerice. One upošljavaju 14.804 osoba, što je $11 \%$ u odnosu na ukupan broj poduzeća u ovom istraživanju. Istovremeno, žene menadžerice ostvaruju 11\% ukupnog prihoda BH privrede te po $12 \%$ izvoza i dobiti. Gledajući ove podatke u kontekstu zastupljenosti po entitetima, žene manadžerice vode $18 \%$ poduzeća iz $\mathrm{FBiH}$ i $20 \%$ poduzeća iz RS.“ (Ključić, 2018.)

\subsection{Sociološko - demografsko okruženje}

Analiza sociološko - demografskog okruženja zasniva se na službenim statističkim podacima institucija u BiH. ${ }^{5}$ Istraživanjem ${ }^{6}$ je utvrđeno slijedeće (Anketa o radnoj snazi, 2018.):

- u ukupnoj populaciji stanovništva u BiH žene čine 50, 90\%

- u ukupnom broju radno sposobnog stanovništva u BiH žene čine 51,20\%

- u ukupnom broju zaposlenih u BiH žene čine 37,40\%

- $\quad$ u ukupnom broju nezaposlenih u BiH žene čine 42,30\%

- u ukupnom broju neaktivnih u BiH žene čine 60,60\%.

Žene kao radno sposobno stanovništvo odnosno zaposlena lica imaju završenu:

- osnovnu školu i manje 46,3\% (radno sposobne), a 16,70\% (zaposlene)

- $\quad$ srednju školu i specijalizaciju 44,3\% (radno sposobne), a 60,70\% (zaposlene)

- visoku, višu, magisterij i doktorat 9,4\% (radno sposobne), a 22,70\% (zaposlene).

2 Op.a. Federacija Bosne i Hercegovine sastoji se od 10 kantona (županija)

3 Op.a. Federacija Bosne i Hercegovine jedan je od dva entiteta u državi Bosni i Hercegovini

4 Op.a. Republika Srpska jedan je od dva entiteta u državi Bosni i Hercegovini

5 Op.a. Agencija za statistiku BiH, Federalni zavod za statistiku i Republički zavod za statistiku RS

6 Op.a. 'Anketa o radnoj snazi' je istraživanje kojim se prikupljaju podaci o osnovnim karakteristikama radno sposobnog stanovništva, a na temelju kojih se vrši procjena ukupne radne snage u zemlji, kao i podaci o demografskim, obrazovnim, socio-ekonomskim i drugim karakteristikama stanovništva u BiH. U aprilu/travnju 2018. godine, izvršeno je 13. istraživanje i publikovana 'Anketa o radnoj snazi (ARS)'. 
Struktura zaposlenih žena u BiH je sljedeća:

- $\quad$ zaposlene $78,90 \%$

- $\quad$ samozaposlene $14,30 \%$

- $\quad$ neplaćeni pomažući članovi 6,80\%.

Struktura zaposlenih žena u BiH prema skupinama područja djelatnosti je sljedeća:

- poljoprivreda $16,00 \%$

- $\quad$ nepoljoprivreda $17,80 \%$

- usluge 66,20\%.

Analizom statističkih podataka na niovu $\mathrm{BiH}$, za 2018. godinu, može se konstantirati da žene, iako čine više od 1/2 ukupne populacije, nemaju adekvatan ekonomski položaj, jer čine nešto više od 1/3 zaposlenih osoba. Jedan od razloga ovakve ekonomske pozicije žena u BH društvu je niska razina obrazovanja žena, kao radno aktivnog stanovništa (46,30\% ima osnovnu školu i manje). Nešto povoljnija situacija je kod zaposlenih žena gdje $60,70 \%$ ima srednju školu i specijalizaciju. Na žalost, žene u BH društvu nemaju razvijene poduzetničke vještine, tako da je većina žena angažirana kod poslodavaca $(78,80 \%)$, odnosno samo manji broj žena opredjeljuje se za samozapošljavanje $(14,30 \%)$ kao oblik eventualnog rješavanja i/ili poboljšanja vlastite ekonomske egzistencije. Kada je u pitanju struktura privrednih djelatnosti u kojima su žene zaposlene, oko $2 / 3$ žena su zaposlene u uslužnim djelatnostima.

\subsection{Tehnološko okruženje}

Tehnološko okruženje u BiH još uvijek nije kreirano kako bi na istovjetan način bilo od koristi svima u BH društvu. Istraživanjem u 2016. godini, utvrđeno je da je u IKT ${ }^{7}$ sektoru, u BiH, bilo zaposleno 29\% žena i 71\% muškaraca (Ključić, 2018.). lako je nedovoljna zastupljenost žena u ovom sektoru, ovaj pokazatelj prilično je optimističan za BH društvo, jer je i u EU 30\% žena zaposleno u IKT sektoru. Jedan od pozitivnih trendova je informacija da su žene u IKT sektoru, u BiH, podjednako plaćene ${ }^{8}$ kao i muškarci.

Internet i društvene mreže dostupne su većini stanovnika u $\mathrm{BiH}$, ali informatička pismenost BH stanovništva još uvijek nije na zavidnom nivou. Internet kao novi medij ujedno je postao i poligon za nasilje nad ženama. Online nasilju nisu izložene samo anonimne pripadnice ženskog spola, nego su žrtve nasilja bile i ugledne javne djelatnice iz BH medija. (E. Ključić, 2017.) To je još jedan od pokazatelja da se suvremeni digitalni mediji i tehnologije u $\mathrm{BiH}$ ne koriste za potrebe osnaživanja žena i promicanje značaja njihove uloge u digitalnoj ekonomiji, nego se koriste za svjesno kršenje zakonom zagarantiranih prava žena, bez ikakvih posljedica za prekršitelje važećih zakona u BiH.

7 Op.a. Informacijsko komunikacijske tehnologije.

8 Op.a. Plata.ba je servis za online istraživanje plaća u sklopu kojeg ispitanici sami unose visine plaća, zbog čega istraživanje uzima u obzir stvarne iznose plaća na bh. tržištu rada. 


\section{REZULTATI ONLINE ANKETE}

Za potrebe potvrđivanja navoda u PEST analizi i ostatku rada, izvršeno je online anketiranje ciljanog uzorka ispitanika. Ciljani uzorak činili su ispitanici oba spola, iz različitih ekonomskih oblasti, a ne isključivo žene poduzetnice. Nadalje, anketirani su ispitanici iz $\mathrm{BiH}$, ali i regije Zapadni Balkan.

Online anketiranjem utvrđeni su sljedeći sumarni rezultati:

- $\quad 50,70 \%$ ispitanika je upoznato sa značenjem pojma feministička ekonomija

- $\quad 94,50 \%$ ispitanika je upoznato sa značenjem pojma žensko poduzetništvo

- $\quad$ 79,20\% ispitanika smatra da tradicionalna ekonomija zanemaruje ulogu žena pri kreiranju bruto domaćeg proizvoda (BDP-a)

- $\quad$ 76,70\% ispitanika ne smatra da se u tradicionalnoj ekonomiji adekvatno mjeri neplaćeni rad, obično žena pri obavljanju kućanskih poslova, brige o djeci i starijima

- $\quad 75,00 \%$ ispitanika ne smatra da je politički i društveni ambijent pogodan za razvoj ženskog poduzetništva

- $\quad 94,50 \%$ ispitanika smatra da se u domicilnim medijima treba veća pažnja posvetiti temi razvoja ženskog poduzetništva

- $\quad 93,20 \%$ ispitanika smatra da informacione tehnologije omogućavaju brži razvoj ženskog poduzetništva

- $\quad$ 79,50\% ispitanika ne smatra da žene imaju jednakopravan položaj u društvu

- $\quad 83,60 \%$ ispitanika ne smatra da je doprinos žena u stvaranju društvenog blagostanja adekvatno vrednovan

- $\quad 98,60 \%$ ispitanika smatra da se sa razvojem ženskog poduzetništva povećava financijska sigurnost žena (i njihovih obitelji).

\section{ULOGA MEDIJA PRI RAZVOJU ŽENSKOG PODUZETNIŠTVA}

Iz prezentiranih podataka u PEST analizi i online anketi uočeni su prilično pesimistični rezultati različitih istraživanja o položaju žena. Položaj žena u $\mathrm{BH}$ društvu i regiji bio bi bolji kada bi se mediji više fokusirali na promociju značaja uloge žena i razvoja ženskog poduzetništva za ekonomiju i društvo. Pristup informacijama omogućava ženama da unaprijede vlastitu egzistenciju i egzistenciju svoje obitelji te tako doprinesu razvoju društvene zajednice i blagostanja u društvu. Na taj način žene mogu bolje donositi odluke o: obrazovanju, proizvodnji, vlasništvu nad imovinom, zdravstvenoj zaštiti, financijskim resursima za postizanje njihovog ekonomskog osnaživanja, ali i da bolje razumiju kako mogu koristiti prava koja su im zagarantirana, kao i da sudjeluju u javnom i političkom životu, i tako u medijskom prostoru artikuliraju problematiku ravnopravnosti spolova i preusmjere trenutne procese pri donošenju budućih političkih odluka. (Ključić, 2018.)

Rodna ravnopravnost upravljačkih struktura u BH medijima nije ništa bolja u odnosu na ostatak BH društva. Udio muškaraca na glavnim upravljačkim pozicijama u BH medijima znatno je veći od udjela žena. Muškarci se nalaze na više od 2/3 direktorskih i pozicija glavnih i odgovornih urednika, dok je udio žena ispod 1/3. Najveća disproporcija u zastu- 
pljenosti žena i muškaraca na glavnim upravljačkim mjestima je u televizijskom sektoru, gdje 3/4 direktora i glavnih i odgovornih urednika u ovom sektoru čine muškarci. Najviše žena na pozicijama glavne i odgovorne urednice je u radijskom sektoru (cca1/2), a najmanje u online sektoru (cca 1/5) zaposlenih žena su na poziciji glavne i odgovorne urednice. (Džihana, 2018.)

Sve dok ne dođe do značajnijih promjena u BH medijima, po pitanju poštivanja Zakona o ravnopravnosti spolova, ne može se očekivati da će doći i do promjene načina informiranja u medijima o npr. značaju doprinosa žena i razvoju ženskog poduzetništva za ekonomski prosperitet društva. To nikako ne znači da žene samo zbog spola trebaju biti imenovane na rukovodeće pozicije u medijima, nego da je za prosperitet društva potrebno u medijima obrađivati teme koje su i u interesu većinske populacije, a to su žene. Promjene u medijima neće se dogoditi same od sebe, kada je u pitanju uređivačka politika i kvaliteta medijskih sadržaja, koji treba da budu rodno osvješteni i afirmativni, kako bi se izvršilo podizanje nivoa svijesti o značaju razvoja ženskog poduzetništva. Poslovne žene u medijima, ali i u drugim srodnim djelatnostima kao što su to: IT, marketing i slično treba da vlastitim primjerom ukazuju na potrebne promjene na medijskoj sceni i da kroz vlastiti profesionalni angažman, naročito putem društvenih mreža ili na drugi način, podižu nivo svijesti o potrebnim promjenama, ne samo u BH društvu i ekonomiji, nego i u regiji.

Ukoliko se u medijima, ali i na drugim mjestima, uskoro ne bude čuo glas muškaraca koji zagovara potrebne promjene u oblasti ravnopravnosti spolova i razvoja ženskog poduzetništva, sva nastojanja žena, bez obzira koliko agilna ona bila, neće uroditi plodom, jer će se trenutno marginaliziranje uloge i značaja žena za BH ekonomiju i društvo, pretvoriti u borbu za ekonomsku i drugu prevlast (i u medijima). To nije cilj žena kada je u pitanju harmonizacija rodnih prava i razvoj ženskog poduzetništva u društvu.

Cilj medija, u narednom periodu, treba biti prvenstveno podizanje razine svijesti i edukacija iz oblasti ravnopravnosti spolova i razvoja ženskog poduzetništva. Na taj način, izvršila bi se harmonizacija trenutnog stanja i osigurali potrebni preduvjeti za dalji razvoj u ovoj oblasti. To se može postići samo adekvatnim informiranjem putem medija, odnosno podizanjem nivoa svijesti stanovništva iz ove oblasti. Velika je profesionalna odgovornost pojedinaca, na glavnim upravljačkim pozicijama u medijima, da izvrše potrebne strukturalne i druge promjene u vlastitom radnom okruženju, kako bi se mogli osjetiti i prvi optimistični pomaci u ovoj oblasti u $\mathrm{BH}$ društvu, ali i regiji.

Tek ukoliko su i djelatnice u medijima sigurne u javnom prostoru, a pri analizi tehnološkog okružanja u BiH utvrđeno je da nisu, može se očekivati da će i djelatnice u drugim sektorima, odnosno općenito žene u BiH biti spremne da se upuste u vlastite poduzetničke poduhvate. Sve dok se takva vrsta promjena ne postigne u BH medijskom prostoru može se konstatirati da se žene psihički svjesno zlostavljaju putem medija, odnosno odgovarajuće uređivačke politike koja se trenutno primjenjuje.

\section{RAZVOJ ŽENSKOG I SOCIJALNOG PODUZETNIŠTVA U BiH}

U medijima pojam poduzetništva najčešće se neadekvatno upotrebljava, odnosno kontinuirano se plasiraju (dez)informacije da su poduzetnici isključivo osobe koje su snažne i odvažne za pokretanje vlastitog posla tj. vlasnici biznisa koji su obično muškog spola. 
„Poduzetništvo je proces u kojem se gradi nešto skoro ni iz čega. Poduzetnica je osoba koja u tom procesu prepoznavanja prilike, skupljanja sredstava za njenu realizaciju i stvaranju (kao i raspodjeli) nove vrijednosti preuzima rizik u novcu, vremenu i ugledu. Žene su tokom cijele povijesti bile poduzetnice, samo se to nije posebno naglašavalo." (Čovo, 2007, 52)

Uslijed nepoznavanja definicije pojma poduzetništva, u medijima se zanemaruje i tema socijalnog poduzetništva, koje se ne odnosi na osnivanje vlastitog biznisa i profesionalnu samoaktualizaciju pojedinaca. Socijalno poduzetništvo koncept je koji integrira stvaranje ekonomske i socijalne vrijednosti. Prisutan je na globalnoj razini, u teoriji i praksi, već jedno stoljeće i jedan je od alata kako se mogu ostvariti kvalitetnije rodna prava žena odnosno osigurati njihova financijska egzistencija i egzistencija njihovih obitelji. Socijalno poduzetništvo je stvaranje socioekonomskih struktura, veza, institucija, organizacija i mjera koje za rezultat imaju održive društvene koristi. Ovaj oblik poduzetničkog ponašanja usmjeren je više na društvene, a ne za profitne ciljeve, gdje se generirani profit koristi za dobrobit određenih (marginaliziranih) društvenih skupina.

Poduzetnički duh veoma je važan za razvoj poduzetničke kulture, ali promocija poduzetničkog duha u domicilnim i regionalnim medijima još uvijek nije na zadovoljavajućem nivou. Informacije iz medija prilično su pesimistične, a poduzetništvo podrazumijeva optimizam, odnosno pozitivno ozračje. Nadalje, mnogi smatraju da se rad, inovatorstvo i razvoj u BiH ne isplati. Vidimo to i iz primjera nezaposlenih majki koje rađaju i odgajaju svoju djecu, odnosno obavljaju tradicionalnu ulogu žene u društvu, ali im ne pripada nikakva zagarantirana, redovna naknada. U ovakvim uvjetima potrebno je da poduzetnice budu istrajne, kreativne i strpljive. Poduzetnice ne trebaju obraćati pažnju na negativno okruženje, koje može samo da poveća njihove strahove i osjećaj nesigurnosti, nego treba da vjeruju u sebe i svoj rad.

Žene u BiH i regiji potrebno je samo malo potaknuti i ohrabriti da se upuste u svijet ženskog poduzetništva. Žensko je poduzetništvo izazovno i raznovrsno, a žene su vješte u multitaskingu. Na taj način poduzetnice mogu ostvariti svoje poslovne vizije i kreativne potencijale. Pozitivna energija koju će osjetiti umrežavajući se s drugim poduzetnicama inspirativna je i daje poduzetnicama snagu da se ide naprijed. Žene koje eventualno imaju dvojbu o ženskom preduzetništvu trebaju znati da je sreća koju će osjetiti, pri poduzimanju poslovnih poduhvata, biti jedan od motivatora za razvoj biznisa, ali da je pri tome potrebno podržati i druge poduzetnice u njihovom nastojanju da budu uspješne u svom poslovanju.

Pozitivnih primjera ima i u BH praksi. Potrebno je da poduzetnice prate i apliciraju na natječaje za poticajna sredstva npr. Federalnog ministarstva razvoja, poduzetništva i obrta koji je namjenjen novoosnovanim poduzećima kao oblik bespovratnih sredstava za financiranje dijela doprinosa za prvu godinu poslovanja i subvencioniranje troškova registracije samostalne djelatnosti ili npr. tekući grant Ministarstva civilnih poslova BiH za sufinanciranje projekata u oblasti Podrške tehničkoj kulturi i inovatorstvu i druge fondove kojima se potiču aktivnosti u oblasti razvoja ženskog poduzetništva. Brojni su pozitivni primjeri žena poduzetnica i načini na koji se može vršiti (su)financiranje vlastitih poduzetničkih poduhvata u $\mathrm{BiH}$, a financijska baza koja podržava razvoj ženskog poduzetništva, iako je ona možda nedostatna, postoji i u BH društvu. Pitanje je samo koliko su mediji dovoljno agilni da informiraju korisnike svojih informacija odnosno BH društvo u cijelosti, kako bi 
se postigla osvještenost žena o ovim trendovima i financijskim mogućnostima za razvoj ženskog i socijalnog poduzetništva u $\mathrm{BiH}$.

Tek kada se podigne nivo svijesti, individualne i kolektivne, o značaju razvoja ženskog i socijalnog poduzetnišva za prosperitet BH društva kao cjeline moći će se očekivati i značajniji razvojni pomaci i potrebne promjene u $\mathrm{BiH}$, a samim time i pozitivni regionalni razvojni trendovi u širem okruženju.

\section{ZAKLJUČAK}

Iz prezentiranih podataka u PEST analizi može se veoma lako uočiti da je položaj većine žena u BH društvu nezavidan, a njihova ekonomska i financijska sigurnost prilično upitna. lako čine više od 1/2 ukupne populacije, žene u BiH nemaju adekvatan ekonomski položaj, jer samo nešto više od $1 / 3$ žena su zaposlene osobe. Pri tome ne treba zaboraviti da su žene u BH društvu i u ovako lošim uvjetima uspjele ne samo da opstanu, nego i da pokreću vlastite biznise, kao i da se istovremeno uspješno brinu za svoje obitelji. Žene menadžerice značajan su faktor BH ekonomskog razvoja. To najbolje svjedoče podaci iz istraživanja u 2017. godini. lako samo 19\% poduzeća vode žene menadžerice, gdje ova poduzeća ostvaruju 11\% ukupnog prihoda $\mathrm{BH}$ privrede, to je tek početak razvoja $\mathrm{BH}$ društva u kojem žene počinju ostvarivati sve veću ekonomsku ulogu.

U suvremenim uvjetima i civilizacijskom trenutku kojeg proživljavamo u 21. stoljeću tradicionalna ekonomija može se značajno obogatiti s pozitivnim praksama iz oblasti ženskog i socijalnog poduzetništva. Cilj takvog obogaćivanja tradicionalne ekonomije prosperitet je $\mathrm{BH}$ ekonomije i društva, ali i regionalni razvoj kroz prekograničnu suradnju. Razmjenom najbolje prakse u oblasti razvoja ženskog poduzetništva i kreiranjem edukativnih programa, za naredne generacije poduzetnica, moguće je kreirati pozitivno ekonomsko-socijalno ozračje koje će za rezultat imati ne samo mjerljivije pokazatelje o doprinosu nevidljivog i neplaćenog rada žena pri kreiranju BDP-a, nego i njihovu ravnopravniju ulogu u ekonomskoj raspodjeli kreiranog blagostanja u $\mathrm{BH}$ društvu, ali i regiji. 


\title{
THE IMPORTANCE OF FEMINIST ECONOMY AND WOMEN ENTREPRENEURSHIP FOR REGIONAL DEVELOPMENT
}

\author{
Lejla Softić, BSc. Econ. \\ SoftConsulting s.p. Tuzla \\ Trg slobode 16, 75000 Tuzla, Bosnia \& Herzegovina (B\&H) \\ Phone: + 38735210 203, e-mail: lejla.softic@savjetnik.ba
}

\begin{abstract}
Regional development cannot be observed without analyzing the problems of the traditional economy, which neglects the role of women in the creation of gross domestic product (GDP). The traditional economy does not adequately measure unpaid work, usually by women in housework, child care and the elderly, and therefore the feminist economy advocates exploring and evaluating the contribution of women's unpaid work in creating GDP. The aim of the research is to present the 'invisible' part of the contribution of women's jobs in the creation of GDP, to highlight the importance of women's entrepreneurship and to stimulate regional development through women's entrepreneurship education. The study uses a PEST analysis for current state of affairs in B\&H, based on secondary data collected from official statistical and other relevant publications that have arisen from primary research on this issue in B\&H. Primary survey of the target sample of respondents from region was conducted, and the results presented in the PEST analysis were confirmed by the online survey. The emphasis in the paper is on the development of women's entrepreneurship, but also on the general socio-economic role of women in the $\mathrm{BH}$ economy, as well as on the importance of raising awareness on this topic in the region. The B\&H Gender Equality Report of the Agency for Gender Equality (2018) states that an equal number of boys and girls, women and men are involved in the B\&H education process, but promotion opportunities for girls/women remain limited and access to positions requiring high qualifications, primarily due to the existence of stereotypes relating to male/female occupations and issues of reconciling work and family life. The position of most women in $\mathrm{BH}$ society is unenviable, and their economic and other security is quite questionable. Despite such poor conditions, women from B\&H have managed to survive, start their own businesses, successfully take care of their families, and become drivers of change in $B \& H$ and regional social development.
\end{abstract}

Keywords: feminist economics; women's entrepreneurship; development 


\section{LITERATURA}

1. Aganović, A., Miftari, E. i Veličković, M. (2015). Žene i politički život u postdejtonskoj Bosni i Hercegovini 1995. - 2015. Preuzeto s https://soc.ba/site/wp-content/uploads/2015/11/19952015-\%C5\%BDene-i-politi\%C4\%8Dki-\%C5\%BEivot-u-postdejtonskoj-Bosni-i-Hercegovini_ za-web.pdf (22.04.2020.).

2. Agencija za ravnopravnost spolova BiH. (2018). Izvještaj o stanju ravnopravnosti spolova u Bosni i Hercegovini 2015. - 2018. Sarajevo: Agencija za ravnopravnost spolova BiH. Preuzeto s https://arsbih.gov.ba/stanje-ravnopravnosti-spolova-u-bosni-i-hercegovini/ (22.04.2020.).

3. Agencija za statistiku Bosne i Hercegovine. (2018). Anketa o radnoj snazi 2018. Sarajevo: Agencija za statistiku Bosne i Hercegovine. Preuzeto s http://www.bhas.gov.ba/data/Publikacije/ Bilteni/2018/LAB_00_2018_Y1_0_BS.pdf (22.04.2020.).

4. Agić, N. (2019). Pregled prava porodilja u BiH: Kolike su razlike među kantonima?. Preuzeto s https://soc.ba/pregled-prava-porodilja-u-bih-koliko-su-razlike-medu-kantonima/ (22.04.2020.).

5. Bašić, S. i Miković, M. (2012). Rodne (ne)jednakosti na tržištu rada u BiH. Preuzeto s https:// library.fes.de/pdf-files/bueros/sarajevo/09705.pdf (22.04.2020.).

6. Čovo, P. (2007). Održivo poduzetništvo. Sveučilište u Zadru. Preuzeto s https://www.bib.irb. $\mathrm{hr} / 361462$ (22.04.2020.).

7. Džihana, A. (2018). Žene i mediji: zaposlenice i upravljačke strukture. Preuzeto s https://bhnovinari.ba/wp-content/uploads/2018/07/Zene-i-mediji-13maj2018-FINAL.pdf (22.04.2020.).

8. Ključić, E. (2017). Pokrenuta inicijativa za kažnjavanje nasilnika. Preuzeto s https://radiosarajevo.ba/vijesti/bosna-i-hercegovina/online-nasilje-priprema/286029 (22.04.2020.).

9. Ključić, E. (2018). Ekonomija, feminizam, internet. Preuzeto s https://zenskaposla. ba/2018/08/13/ekonomija-feminizam-internet/ (22.04.2020.).

10. Ključić, E. (2018). Feminizam i internet: korištenje tehnologije. Preuzeto s https://zenskaposla. ba/2018/05/29/feminizam-i-internet-koristenje-tehnologije/ (22.04.2020.).

11. Ključić, E. (2018). Feminizam i internet: pristup informacijama. Preuzeto s https://zenskaposla. ba/2018/05/22/feminizam-i-internet-pristup-informacijama/ (22.04.2020.).

12. Knežević, M. (2016). Ekonomske mogućnostiza žene iz malih lokalnih zajednica. Preuzeto s http:// www.fondacijacure.org/files/zalagackeplatforme/Ekonomske\%20mogu\%C4\%87nosti\%20 za\%20\%C5\%BEene\%20iz\%20malih\%20lokalnih\%20zajednica\%20u\%20BiH.pdf (22.04.2020.).

13. Miftari, E. (2017). Izvještaj o lokalnim politikama u općinama i gradovima BiH. Preuzeto s http://fondacijacure.org/files/Lokalne\%20politike\%20za\%20ravnopravnost\%20spolova\%20 u\%20BiH.pdf (22.04.2020.).

14. Miftari, E. (2019). Violence Against Women in Politics in Bosnia and Herzegovina. Preuzeto s https://www.wfd.org/wp-content/uploads/2019/07/Violence-Against-Women-in-PoliticsBiH-WFD2019.pdf (22.04.2020.). 